\title{
Antioxidant activity and hepatoprotective potential of Cedrelopsis grevei on cypermethrin induced oxidative stress and liver damage in male mice
}

\author{
Abdel-Tawab H. Mossa ${ }^{1 *}$, Tarek M. Heikal ${ }^{1}$, Meriam Belaiba ${ }^{2}$, Emmanuel Guy Raoelison ${ }^{3}$, Hicham Ferhout ${ }^{4}$
} and Jalloul Bouajila $2^{2^{*}}$

\begin{abstract}
Background: The liver is the most sensitive and main target organ of pesticide toxicity and damage, they play an essential role in metabolism and detoxification of pesticides. Due to these functions, hepatotoxicity continues to be among the main threats to public health, and they remain problems throughout the world. Therefore, the present study was designed to evaluate the antioxidant and hepatoprotective effects of Cedrelopsis grevei leaves against cypermethrin (Суp) induced oxidative stress and liver damage in male mice.

Methods: The extracts were subjected to different analyses (phenolics, tannin, flavonoids, antioxidant activity and reducing power assays). For hepatoprotective evaluation, male mice were daily exposed to Cyp and/or C. grevei by gavages for 28 days. Hepatoprotective effects were demonstrated by significant alterations in serum liver dysfunction biomarker enzymes, liver lipid peroxidation and antioxidant enzymes.

Results: The antioxidant activity of $C$. grevei methanolic extract was the highest with an $\mathrm{IC}_{50}<225 \mu \mathrm{g} / \mathrm{ml}$ by DPPH assay. The high dose of methanolic extract (300 mg/kg. b.wt.) was effective to attenuate the perturbations in the tested enzymes. Histopathological examination in the liver tissue of those mice, demonstrated that a co-administration of methanolic extract ( 150 \& $300 \mathrm{mg} / \mathrm{kg} /$ day) showed marked improvement in its histological structure in comparison to Cyp-treated group alone and represented by nil to moderate degree in inflammatory cells.

Conclusions: In view of the data of the present study, it can deduce that cypermethrin caused oxidative damage and liver dysfunction in male mice. C. grevei extract has protective effects on cypermethrin-induced lipid peroxidation, oxidative stress and liver damage. Results indicated that administration of C. grevei is useful, easy, and economical to protect humans against pesticide toxicity. The results presented here can be considered as the first information on the hepatoprotective and antioxidant properties of C. grevei extracts. In a future study, we will identify and investigate the components responsible for the hepatoprotective and antioxidant activities of $C$. grevei.
\end{abstract} Keywords: Cedrelopsis grevei, Antioxidant, Hepatoprotective, Cypermethrin, Oxidative stress, Liver damage, Mice

\footnotetext{
*Correspondence: abdeltawab.mossa@yahoo.com; jalloul.bouajila@univ-tlse3.fr

'Environmental Toxicology Research Unit (ETRU), Pesticide Chemistry

Department, National Research Centre (NRC), 33 El Bohouth Street (former El Tahrir St.), P.O. 12622, Dokki, Giza, Egypt

${ }^{2}$ Faculté de pharmacie de Toulouse, Laboratoire des Interactions Moléculaires et Réactivité Chimique et Photochimique UMR CNRS 5623, Université de Toulouse, Université Paul-Sabatier, 118 route de Narbonne, F-31062 Toulouse, France

Full list of author information is available at the end of the article
} 


\section{Background}

Pesticides have been applied in agriculture and household to protect plants, animals and human from insects and vector diseases. The negligent and random uses of pesticides can cause environmental damage, food, water contamination, and health problems (e.g. cancer, nerve disease, birth defects). Cypermethrin (Cyp), a class II pyrethroid pesticide, first synthesized in 1974, widely used to control many pest species in agriculture, animal breeding and the household [1]. It has been reported that Cyp residues were found in the air, on walls and furniture after three months of household treatments [2]. Cyp was accumulated in adipose tissue, brain and liver of rats $[3,4]$ and has hepatotoxic potential in rodents $[2,5]$. It crosses the blood-brain barrier and induces neurotoxicity and motor deficits [6]. However, due to the low toxicity of pyrethroids, persistence of these insecticides in mammalian tissues may be dangerous [3].

In fact, one possible mechanism of pesticide-induced toxicity is the production of reactive oxygen species (ROS) in the cell. ROS can alter oxidant/prooxidants statues and antioxidant defense system by increasing lipid peroxidation (LPO) and depleting the antioxidants in cell (enzymatic and non-enzymatic) which leading to a condition of oxidative stress [7]. It has been reported that ROS were involved in the toxicity of organophosphate insecticides (OPIs) such as chlorpyrifos [7] and pyrethroid insecticides such as prallethrin $[8,9]$ and a positive correlation with the liver damage has been reported. ROS, especially superoxide anion and hydrogen peroxide, are important signaling molecules in developing and proliferating cells, but also in the induction of programmed cell death [10]. ROS are transient species due to its high chemical reactivity that leads to the LPO and a massive protein oxidation and degradation $[11,12]$. The author reported that ROS cause DNA damage and strand breaks as a result of modifying purines and pyrimidines bases by superoxide anion radical $\left(\mathrm{O}_{2}^{--}\right)$, hydrogen peroxide $\left(\mathrm{H}_{2} \mathrm{O}_{2}\right)$, and hydroxyl radical $\left(\mathrm{HO}^{\circ}\right)$.

Cedrelopsis grevei is an endemic species in Madagascar. It was used in traditional medicine to treat malaria, fever and fatigue [13]. Our previous study [14] showed that sixty-four components were identified in C. grevei essential oil by GC-MS. The major constituents were: (E)- $\beta$ farnesene $(27.61 \%), \delta$-cadinene $(14.48 \%)$, $\alpha$-copaene (7.65 \%) and $\beta$-elemene (6.96\%). It exhibited antioxidant activities and concentration-dependent inhibitory effects on $\mathrm{DPPH}^{*}$ and ABTS. Previous investigations of the trunk [15] and stem [16] bark of C. grevei showed that five coumarins i.e. norbraylin, methyl-O-cedrelopsin, cedrecoumarin A, scoparone and braylin were isolated. Atmaca et al. [17] showed that hepatoprotective effect of coumarins against oxidative stress and liver damage induced by carbon tetrachloride in male rats. In addition, phenolic compounds of $C$. grevei are playing an essential role in neutralizing free radical, quenching singlet and triplet oxygen, decomposing peroxides, stabilizing lipid peroxidation and protecting the cells against oxidative damage [18].

Currently, some synthetic antioxidant use to prevent free radical damage can induce side effects [19]. So, the dietary intake of natural products is considered very important for preventing a wide variety of diseases, including allergies, cardiovascular disease, certain forms of cancer, hepatic diseases, and inflammation, which involve free radical-mediated damage in pathologically generating processes [20]. Therefore, that is an essential research about suitable herbal drugs, that could replace the chemical ones [21]. However, the widespread use of C. grevei in traditional medicine stimulated us to explore its potential biological activity. To the best of our knowledge, no previous study of the antioxidant and hepatoprotective activities of $C$. grevei leaves extract have been reported. Therefore, the current study was designed to evaluate the antioxidant activity and hepatoprotective effect of $C$. grevei leaves against Cyp induced oxidative stress, lipid peroxidation and liver damage in male mice.

\section{Materials and methods \\ Chemicals and reagents}

The assay kits used for biochemical measurements of aspartate aminotransferases (AST; EC 2.6.1.1.), alanine aminotransferases (ALT; EC 2.6.1.2), alkaline phosphatase (ALP; EC 3.1.3.1), lactate dehydrogenase (LDH; EC 1.1.1.27), catalase (CAT; EC 1.11.1.6), superoxide dismutase (SOD; EC 1.15.1.1), glutathione-s-transferase (GST; EC 2.5.1.18), glutathione reduced (GSH), malondialdehyde (MDA) and total protein were purchased from Biodiagnostic Company, Dokki, Giza, Egypt. Cypermethrin (95.1 \%) was obtained from Jiangsu Yangnong Chemical Co., Ltd, China. All other chemicals used were of analytical reagent grade. All reagents were purchased from SigmaAldrich-Fluka (Saint-Quentin France).

\section{In vitro studies \\ Plant material and extraction}

The leaves of $C$. grevei was collected from Toliara, Madagascar and identified by Benja RAKOTONIRINA (Institut malgache de recherches appliquées (IMRA), Madagascar). A voucher specimen (No. TLR 07) was deposited at the Herbarium of IMRA, Madagascar. The leaves of C. grevei collected in Antananarivo, Madagascar were ground to fine powder and successively extracted with solvents of increasing polarity (cyclohexane, dichloromethane, ethyl acetate, ethanol and finally methanol). Thus, $200 \mathrm{~g}$ of leaves powder were placed in steeping with cyclohexane $(2 \mathrm{~L})$ for $4 \mathrm{~h}$ under frequent agitation at ambient temperature and pressure. The mixture was 
then filtrated using Wattman Paper (GF/A, $110 \mathrm{~mm}$ ). The solvent was evaporated by rotary evaporation under vacuum at $30{ }^{\circ} \mathrm{C}$. Then, the same powder extracted with cyclohexane was extracted again with the next solvent, dichloromethane, under the same conditions. The same protocol was applied for ethyl acetate, ethanol and methanol. Extracts were subsequently stored in sealed and amber vials at $4{ }^{\circ} \mathrm{C}$ for the following analysis.

\section{Photochemical study \\ Determination of phenolic contents}

The phenolic content of each extract was determined by Folin-Ciocalteu method [22]. Briefly, a mixture of diluted solution $(20 \mu \mathrm{L})$ of each extract and $100 \mu \mathrm{L}$ of FolinCiocalteu reagent $(0.2 \mathrm{~N})$ were prepared. The mixture was incubated for $5 \mathrm{~min}$ at room temperature and then $80 \mu \mathrm{L}$ of sodium carbonate solution $(75 \mathrm{~g} / \mathrm{L}$ in water) was added. The absorbance was read at $765 \mathrm{~nm}$, after $1 \mathrm{~h}$ against water blank. A standard calibration curve was plotted using gallic acid (0-300 mg/L). Results were expressed as $\mathrm{g}$ of gallic acid equivalents (GAE)/ $\mathrm{Kg}$ of dry mass.

\section{Determination of flavonoids contents}

The flavonoids were determined by Dowd method [22]. A mixture of diluted solution $(100 \mu \mathrm{L})$ of each extract and $100 \mu \mathrm{L}$ of aluminum trichloride $\left(\mathrm{AlCl}_{3}\right)$ in methanol (2\%) were prepared. The absorbance of the mixture was measured at $415 \mathrm{~nm}$, after $15 \mathrm{~min}$. At the same time, a blank sample formed by methanol $(100 \mu \mathrm{L})$ and extract $(100 \mu \mathrm{L})$ without $\mathrm{AlCl}_{3}$. The results were expressed as $\mathrm{g}$ of quercetin equivalents $(\mathrm{QE}) / \mathrm{Kg}$ of dry mass from calibration curve.

\section{Determination of anthocyanin content}

The absorbance of the extract was measured at 510 and $700 \mathrm{~nm}$ in buffers at $\mathrm{pH} 1.0$ (hydrochloric acid-potassium chloride, $0.2 \mathrm{M}$ ) and 4.5 (acetic acid-sodium acetate, $1 \mathrm{M})$ [22] using 96-well plates. $20 \mu \mathrm{l}$ extract solution was mixed with $180 \mu \mathrm{l}$ of buffers and the wavelength reading was performed after $15 \mathrm{~min}$ of incubation. Anthocyanin contents were calculated using a molar extinction coefficient $(\varepsilon)$ of 29600 (cyanidin-3-glucoside) and absorbance of $A=\left[\left(A_{510}-A_{700}\right)_{\mathrm{pH} 1.0}-\left(A_{510}-A_{700}\right)_{\mathrm{pH} 4.5}\right]$.

\section{Determination of tannin content}

Proanthocyanidins reactive to vanillin were analyzed by the vanillin method [22]. One milliliter of extract solution was placed in a test tube together with $2 \mathrm{~mL}$ of vanillin ( $1 \%$ in $7 \mathrm{M} \mathrm{H}_{2} \mathrm{SO}_{4}$ ) in an ice bath and then incubated at $25{ }^{\circ} \mathrm{C}$. After $15 \mathrm{~min}$, the absorbance of the solution was read at $500 \mathrm{~nm}$.

\section{Antioxidant activity}

The free radical scavenging activities by $\mathrm{DPPH}^{\bullet}$ and ABTS $^{*+}$ assays were evaluated according to the method cited by Afoulous et al. [14]. Total reducing capacity of C. grevei extracts was determined according to the method of Oyaizu [23]. One $\mathrm{mL}$ of extract at different concentrations $(250-1000 \mu \mathrm{g} / \mathrm{ml})$ were mixed with $2.5 \mathrm{ml}$ phosphate buffer $(0.2 \mathrm{M}, \mathrm{pH} 6.6)$ and $2.5 \mathrm{~mL}$ potassium ferricyanide $\left[\mathrm{K}_{3} \mathrm{Fe}(\mathrm{CN})_{6}\right](1 \%)$. The mixture was incubated at $50{ }^{\circ} \mathrm{C}$ for $20 \mathrm{~min}$, and then a portion $(2.5 \mathrm{ml})$ of TCA $(10 \%)$ was added to the mixture, which was centrifuged for $10 \mathrm{~min}$ at $1000 \mathrm{x}$ g. The upper layer of solution $(2.5 \mathrm{ml})$ was mixed with distilled water $(2.5 \mathrm{ml})$ and $0.5 \mathrm{~mL} \mathrm{FeCl} 3(0.1 \%)$. Then the absorbance was measured at $700 \mathrm{~nm}$. Ascorbic acid $(0.5-10 \mu \mathrm{g} / \mathrm{ml})$ was used as the reference compound.

\section{In vivo studies}

\section{Animals and treatments}

Healthy adult male mice weighing $22.5 \pm 1.0$ g were obtained from the Animal Breeding House of the National Research Centre (NRC), Dokki, Giza, Egypt. Animals were housed in clean plastic cages in the laboratory animal room $\left(23 \pm 2{ }^{\circ} \mathrm{C}\right)$ on the standard pellet diet and tap water ad-libitum, a minimum relative humidity of $40 \%$ and a $12 \mathrm{~h}$ dark/light cycle. Mice were allowed to acclimate to laboratory conditions for 7 days prior to dosing. The experimental work on mice was performed with the approval of the Animal Care \& Experimental Committee, National Research Centre, Giza, Egypt, and international guidelines for the care and use of laboratory animals.

Animals were randomly divided into six groups (six mice each), control, Cyp, extract (150 and $300 \mathrm{mg} / \mathrm{kg}$. b.wt), Cyp plus extract (150 or $300 \mathrm{mg} / \mathrm{kg}$. b.wt) groups. Cyp and C. grevei extracts were administered by gavages in a fixed volume of $0.1 \mathrm{ml} / \mathrm{mice}$ daily for 28 days. Cyp was dissolved in corn oil and given via oral route at dose $13.8 \mathrm{mg} / \mathrm{kg}$ b.wt $1 / 10 \mathrm{LD}_{50}$ [24]. C. grevei extracts were dissolved in water and given via oral route at dose 150 and $300 \mathrm{mg} / \mathrm{kg}$ b.wt. Dosages were freshly prepared, adjusted weekly for body weight changes, while a control group was received corn oil.

\section{Sample collections}

At the end of the experiment, blood samples were drawn from the retro-orbital venous plexus of the animals in glass tubes. Within $20 \mathrm{~min}$ of blood collection, the sera were drawn after centrifugation at $3500 \mathrm{rpm}$ for $10 \mathrm{~min}$ at $4{ }^{\circ} \mathrm{C}$. The sera were kept in a deep freezer $\left(-20{ }^{\circ} \mathrm{C}\right)$ for biochemical analysis. Portions of liver from all animals in each group were homogenized in $50 \mathrm{mM}$ Tris- $\mathrm{HCl}$ buffer ( $\mathrm{pH}$ 7.4) containing $1.15 \%$ potassium chloride. The homogenates were centrifuged at 10,000 g for $15 \mathrm{~min}$ at $4{ }^{\circ} \mathrm{C}$. The collected supernatants were used for the 
Table 1 Solvents extract and yield of Cedrelpsis grevei

\begin{tabular}{llllll}
\hline Solvents & Cyclohexane & Dichloromethane & Acetate ethyl & Ethanol & Methanol \\
\hline $\mathrm{N}$ & 1 & 3 & 2 & 2 & 1 \\
Yield $(\mathrm{g} / 100 \mathrm{~g})$ & 2.1 & 4.6 & 0.44 & 2.2 & 0.8 \\
\hline
\end{tabular}

$\mathrm{N}$, number of extractions; C. grevei leaves weights $200 \mathrm{~g}$ dry weight; solvent $=2$ liter; extraction after $4 \mathrm{~h}$ of steeping

estimation of the activities of CAT, SOD, GST enzymes and the contents of GSH and LPO.

\section{Body weights and relative liver weights}

During the experimental period, body weight changes of male mice were recorded weekly. At the end of treatments, the mice were sacrificed by cervical dislocation. Liver of mice was quickly removed, cleaned, weighed and used for biochemical and histological studies. Then, relative weight of liver was calculated.

\section{Biochemical measurements}

All biochemical measurements (AST, ALT, ALP, LDH, SOD, CAT, GST, MDA, and GSH) were determined using commercial kits in accordance with manufacturers' instructions using a spectrophotometer (Shimadzu UV-VIS Recording 2401, PC, Japan).

\section{Histological study}

Small pieces of liver samples from each group were dissected and fixed in $10 \%$ neutral formalin, dehydrated in ascending grades of alcohol and embedded in paraffin wax. Paraffin sections (5 $\mu \mathrm{m}$ thick) were stained for routine histological study using haematoxylin and eosin (H\&E). Two slides were prepared for each mice; each slid content two sections. Ten field areas for each section were selected and examined for histopathological changes (x160) under light microscope. According to Michael [25], the liver fields were scored as follows: normal appearance (-), minimal cellular disruption in less than $1 \%$ of field area $(+)$, mild cellular disruption of $1-30 \%$ of field area $(++)$, moderate cellular disruption of $31-60 \%$ of field area $(+++)$, severe cell disruption of $61-90 \%$ of field area $(++++)$ and very severe cellular disruption of $91-100 \%$ of field area $(++++)$.

\section{Statistical analysis}

The results were expressed as means \pm S.D. All data were done with the Statistical Package for Social Sciences (SPSS 17.0 for windows). The results were analyzed using one way analysis of variance (ANOVA) followed by Duncan's test for comparison between different treatment groups. Statistical significance was set at $P \leq 0.05$.

\section{Results}

The highest yield of C. grevei was obtained with the dichloromethane extract $(4.6 \%)$ of the plant material. While, the low yield was observed with the ethyl acetate extract $(0.44 \%)$. This variation in the yields of different extracts can be explained by the difference of polarity for compounds present in the plant (Table 1). Methanolic and ethanolic extracts of $C$. grevei were found to have high total phenolic content, $41.67 \pm 0.19$ and $39.12 \pm 0.44 \mathrm{~g}$ GAE/Kg ES, respectively (Table 2 ). So, in the present study, the polar extracts containing the highest amount of phenolic (EtOH and $\mathrm{MeOH}$ ) were selected for the further analysis. The ethanol extract is the richest by tannins with $22.14 \pm 1.03 \mathrm{~g} \mathrm{EC} / \mathrm{kg}$ ES, followed by methanol extract with $12.69 \pm 0.63 \mathrm{~g} \mathrm{EC} / \mathrm{Kg}$ ES. The ethanolic and methanol extracts have obtained intermediate values for anthocyanins (respectively $1.86 \pm 0.13$ and $1.35 \pm 0.08 \mathrm{~g}$ $\mathrm{C} 3 \mathrm{GE} / \mathrm{Kg}$ ES) (Table 2), while flavonoids not detected.

Figure 1 illustrates a decrease in the concentration of DPPH radical due to the scavenging ability of C. grevei extracts. On DPPH radical, EtOH and $\mathrm{MeOH}$ had scavenging effects with increasing concentration in the range of $95-400 \mu \mathrm{g} / \mathrm{mL}$, and the scavenging effect of EtOH was lower than $\mathrm{MeOH}$. The $\mathrm{IC}_{50}$ value of ascorbic acid was $4.7 \mu \mathrm{g} / \mathrm{mL}$. $\mathrm{MeOH}$ extract $(400 \mu \mathrm{g} / \mathrm{mL})$ exhibited the highest inhibition of about $69.45 \%$, but this is lower in EtOH extract whose percentage of inhibition is $61.27 \%$. ABTS assay is shown in Fig. 2. C. grevei extracts $(100 \mu \mathrm{g} /$ $\mathrm{mL}$ ) exhibited the highest inhibition of $76.81 \%$ and $78.35 \%$ of $\mathrm{MeOH}$ and $\mathrm{EtOH}$ extracts. As illustrated in Fig. 3, $\mathrm{Fe}^{3+}$ was transformed to $\mathrm{Fe}^{2+}$ in the presence of $\mathrm{MeOH}$ and $\mathrm{EtOH}$ extracts of C. grevei to measure the reductive capability. C. grevei extracts had significant inhibition of reducing power with increasing concentration in the range of $0.10-0.125 \mathrm{mg} / \mathrm{mL}$.

In the present study, the body weight loss was markedly observed of mice treated with Cyp compared to the control group (Fig. 4A). The difference between the two groups was statistically significant (30.38 g vs. $32.82 \mathrm{~g}$,

Table 2 Chemical composition of $C$. grevei leaves extracts

\begin{tabular}{lllll}
\hline Extract & Phenolics (g GAE/Kg ES) & Flavonoids (g QE/Kg ES) & Tannins (g CE/Kg ES) & Anthocyanins (g C3GE/Kg ES) \\
\hline Ethanol & $39.12 \pm 0.44^{\mathrm{b}}$ & nd & $22.14 \pm 1.03^{\mathrm{a}}$ & $1.86 \pm 0.13^{\mathrm{b}}$ \\
Methanol & $41.67 \pm 0.19^{\mathrm{a}}$ & nd & $12.69 \pm 0.63^{\mathrm{b}}$ & $1.35 \pm 0.08^{\mathrm{d}}$ \\
\hline
\end{tabular}




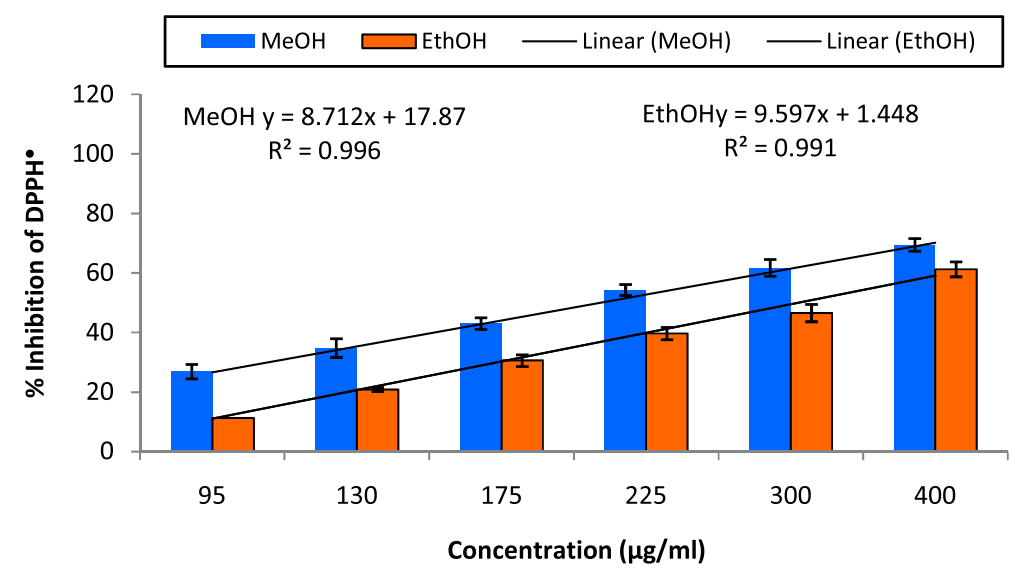

Fig. 1 DPPH radical scavenging activity (\%) of $\mathrm{MeOH}$ and EthOH extracts of C. grevei. Bars represent the mean \pm SD

$P \leq 0.05)$. Co- administration of C. grevei (MeOH extract) at $300 \mathrm{mg} / \mathrm{kg}$ b.wt. to mice of Cyp group restored body weight to normal range (33.81 g vs. $32.82 \mathrm{~g}$ ). As shown in Fig. 4B, significant decrease in relative liver weight was observed after treatment of mice with Cyp compared to control group (5.44 \% g vs. $4.88 \% \mathrm{~g}$ ). Co-administration of $C$. grevei at $150 \& 300 \mathrm{mg} / \mathrm{kg}$ b.wt. with Cyp modulated significantly relative live weight to the normal control value ( $4.98 \%, 4.91 \%$ vs. $4.88 \%)$.

The oral administration of the two tested doses of C. grevei extract ( $150 \& 300 \mathrm{mg} / \mathrm{kg} /$ day) to normal mice produced no changes in all serum biochemical parameters of liver compared to the normal control mice (Table 3). In contrast, male mice exposed to Cyp $(13.80 \mathrm{mg} / \mathrm{kg} /$ day $)$ induced a severe hepatic damage in serum enzyme activities of ALT, AST and ALP levels comparable to control (Table 3). Also in Cyp-treated mice, serum LDH activity was increased by $37.53 \%$, while it was decreased by $-27.84 \%$ in the liver homogenate. However, coadministration of $C$. grevei extract to Cyp-treated mice resulted in a partial recovery in the above-mentioned parameters (AST, ALT, ALP and LDH) in a dose dependent manner. The high dose of C. grevei extract $(300 \mathrm{mg} / \mathrm{kg})$ was more effective than low dose $(150 \mathrm{mg} / \mathrm{kg})$ to attenuate the perturbations in the tested enzymes (Table 3).

In the liver homogenates of Cyp-treated mice, the activities of SOD, CAT, GST and the level of GSH decreased significantly $(P \leq 0.05)$ by $20.5 \%, 38.5 \%, 18.6 \%$ and $30.1 \%$, respectively, while the level of MDA increased significantly $(P \leq 0.05)$ by $51.0 \%$ when compared to the corresponding controls (Table 4). In this study, MDA level increased in mice exposed to Cyp. Co-administration of C. grevei extract to Cyp-treated mice resulted in a partial recovery in the above-mentioned parameters in a dose dependent manner. The high dose of C. grevei extract $(300 \mathrm{mg} / \mathrm{kg})$ was more effective than low dose $(150 \mathrm{mg} / \mathrm{kg})$ to attenuate the perturbations in the tested enzymes (Table 4).

The representative picutures of histopathological examination of the liver tissue are shown in Fig. 5 (A-D) and

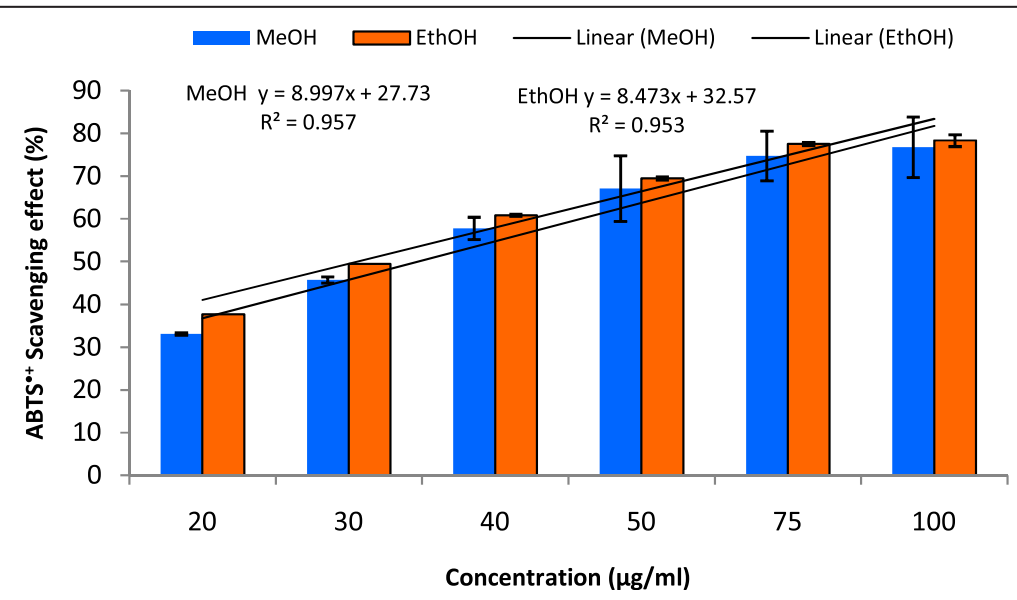

Fig. $2 \mathrm{ABTS}^{++}$Scavenging activity (\%) of $\mathrm{MeOH}$ and EthOH extracts of $\mathrm{C}$. grevei. Bars represent the mean $\pm \mathrm{SD}$ 


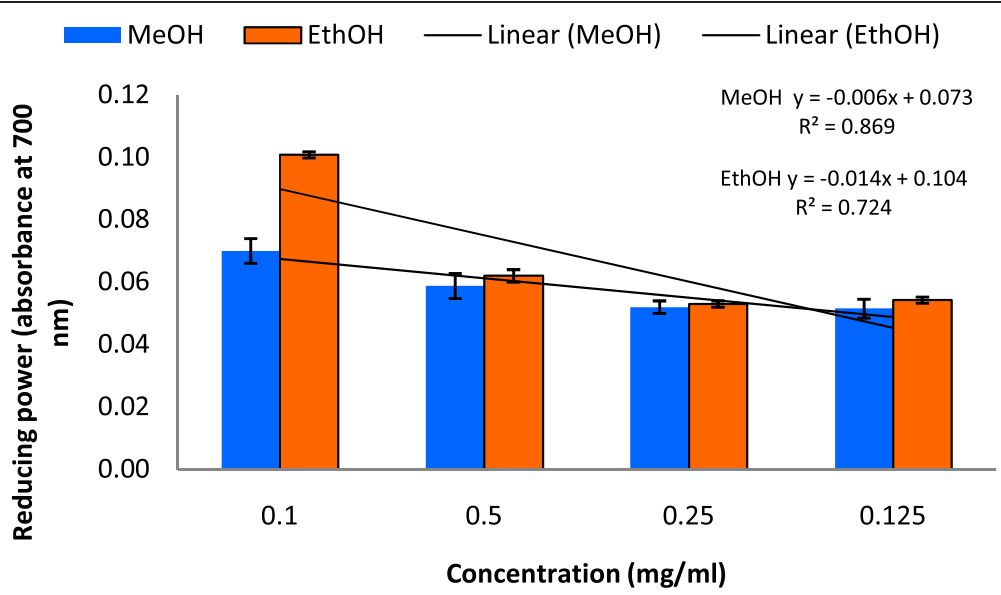

Fig. 3 Reducing power (absorbance at $700 \mathrm{~nm}$ ) of $\mathrm{MeOH}$ and EthOH extracts of C. grevei. Values are mean \pm SD
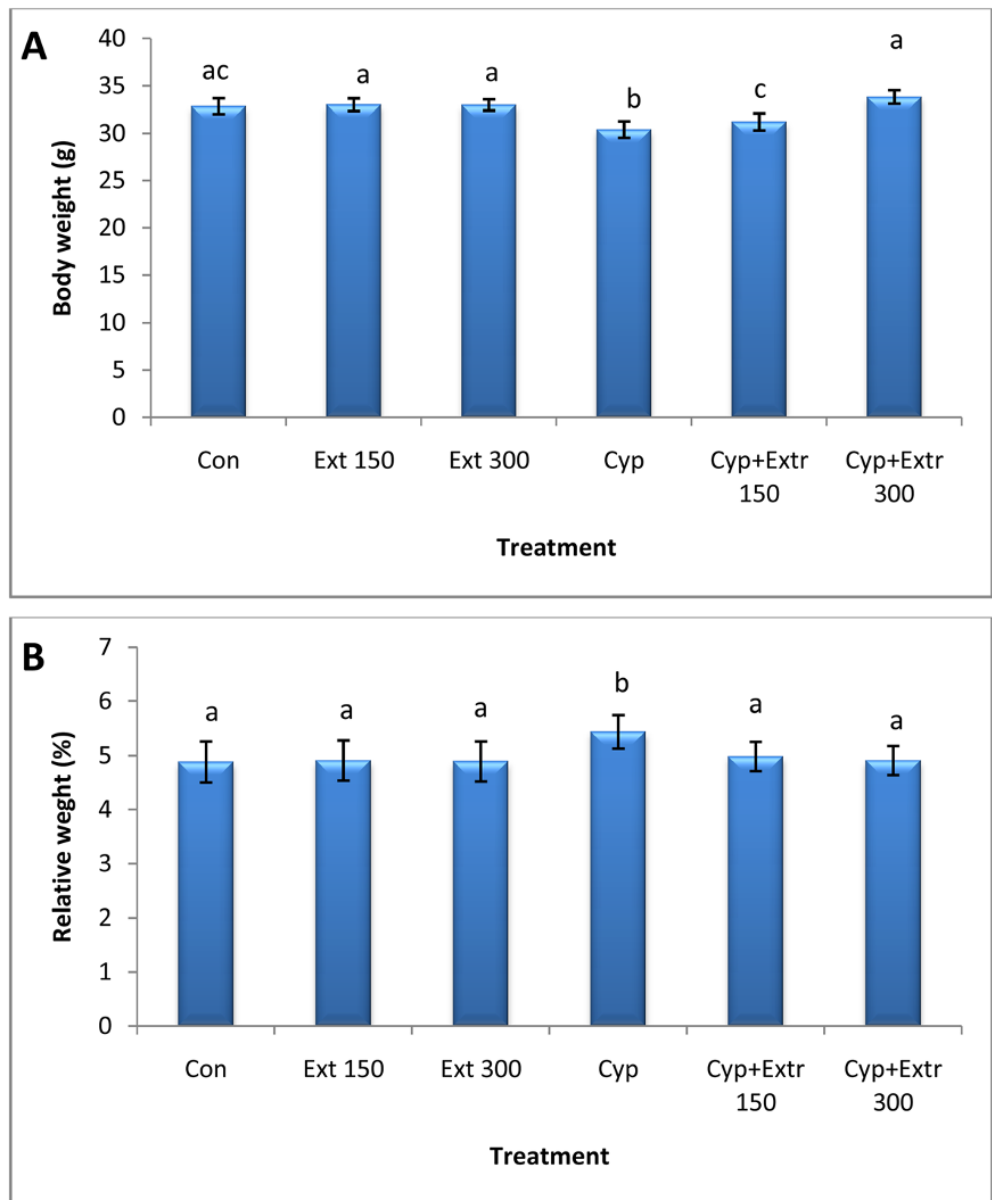

Fig. 4 Body (a) and relative liver (b) weights of rats exposed to cypermethrin (Cyp) and the protective effect of $\mathrm{C}$. grevei (MeOH extract). Bars represent the mean of 6 mice \pm SD; values are not sharing superscripts letters $(a, b, c, d, e)$ differ significantly at $P \leq 0.05$. Relative liver weight (\%) $=($ liver weight/body weight) X 100. Con: control; Cyp: cypermethrin; Ext 150: 150 mg/kg b.wt of C. grevei extract; Ext 300: 300 mg/kg b.wt of C. grevei extract (MeOH extract) 
Table 3 Effect of C. grevei MeOH extract on SOD, CAT, GST, LPO and GSH in liver of mice exposed to cypermethrin

\begin{tabular}{|c|c|c|c|c|c|}
\hline Treatments & $\mathrm{SOD}(\mathrm{U} / \mathrm{g}$ tissue $))$ & CAT(U/g tissue) & GST(U/g tissue) & LPO(nmol/g tissue) & $\mathrm{GSH}(\mathrm{mmol} / \mathrm{g}$ tissue $)$ \\
\hline Control & $664.20 \pm 8.58^{c}$ & $298.68 \pm 4.47^{c}$ & $2018.51 \pm 63.92^{c}$ & $295.42 \pm 8.12^{a}$ & $155.11 \pm 3.02^{c}$ \\
\hline Ext 150 & $668.74 \pm 17.49^{c}$ & $292.59 \pm 8.34^{c}$ & $2093.45 \pm 31.66^{c}$ & $298.03 \pm 9.45^{a}$ & $157.18 \pm 2.85^{c}$ \\
\hline Ext 300 & $676.82 \pm 20.47^{c}$ & $297.95 \pm 5.17^{c}$ & $2157.52 \pm 32.78^{c}$ & $292.38 \pm 7.25^{\mathrm{a}}$ & $159.99 \pm 3.07^{c}$ \\
\hline Сур & $527.93 \pm 19.46^{\mathrm{a}}$ & $183.67 \pm 6.38^{\mathrm{a}}$ & $1642.73 \pm 52.93^{\mathrm{a}}$ & $446.19 \pm 13.78^{c}$ & $108.48 \pm 3.93^{\mathrm{a}}$ \\
\hline Cyp+ Ext 150 & $609.69 \pm 17.84^{b}$ & $272.15 \pm 6.78^{b}$ & $1710.54 \pm 53.95^{\mathrm{ab}}$ & $409.15 \pm 20.25^{c}$ & $120.03 \pm 6.18^{a}$ \\
\hline Cyp+ Ext 300 & $632.40 \pm 22.02^{\mathrm{bc}}$ & $287.87 \pm 9.92^{b c}$ & $1808.70 \pm 52.66^{b}$ & $369.50 \pm 14.58^{b}$ & $135.57 \pm 4.39^{b}$ \\
\hline
\end{tabular}

Each value is a mean of 6 animals \pm SD.; ${ }^{a}, b, c$, d values are not shared superscripts letters (a, b, c, d) differ significantly at $P \leq 0.05$; Con: control; Cyp: cypermethrin; Ext 150 \& Ext 300; 150 and 300 mg/ kg b.wt of C. grevei extract. SOD: superoxide dismutase; CAT: catalase; GST: glutathione-S-transferase; LPO: lipid peroxidation; GSH: glutathione reduced

the semi quantitative histological scoring of liver damage is presented in Table 5. Liver sections from the control group mice showed normal hepatic cytoarchitecture. They formed of hepatocytes radiating from central vein to the periphery of the lobules (Fig. 5A). Liver lobules of Cyptreated mice showed severe degeneration in hepatocytes, necroses, dilation of portal vein with inflammatory cell infiltration in the portal area (Fig. 5B). Liver sections of mice treated with Cyp + Ext 150 (Fig. 5C) showed mild to moderate dilatation of central vein and ballooning degeneration in surrounding hepatocytes. Whereas, in cypermethrin + Ext 300 treated mice (Fig. 5C) showed only moderate dilatation of portal vein.

\section{Discussion}

The natural antioxidants present in many plants reduce oxidative damage and help prevent mutagenesis, carcinogenesis and aging due to their radical scavenging activities $[8,20]$. Therefore, phenolic compounds of plants are very important because their hydroxyl groups confer antioxidant activity. Results of the present study showed that phenolics content of methanol and ethanol extract of C. grevei were similar quantities. However, no work in the literature cited the quantification of phenolic compound of that family. We have not detected flavonoids. These results are contradictory to those presented by the study of Paris and Debray [26], which showed that the leaves of C. grevei contain $2 \%$ flavonoids as glycosides of flavonols. The ethanol extract is the richest by tannins, followed by methanol extract. In addition, the ethanolic and methanol extracts have obtained intermediate values for anthocyanins [26].

Free radicals are continuously produced in body and cause the oxidation of biomolecules (e.g., protein, amino acids, lipid and DNA) which leads to cell injury and death. Our results revealed that $\mathrm{EtOH}$ and $\mathrm{MeOH}$ extract of $C$. grevei had DPPH scavenging activity in a concentration depending manner. C. grevei extracts $(100 \mu \mathrm{g} / \mathrm{mL})$ exhibited the highest inhibition of ABTS. In reducing power assay, $\mathrm{Fe}^{3+}$ was transformed to $\mathrm{Fe}^{2+}$ in the presence of $\mathrm{MeOH}$ and $\mathrm{EtOH}$ extracts of $C$. grevei to measure the reductive capability. C. grevei extracts had significant inhibition of reducing power with increasing concentration in the range of $0.10-0.125 \mathrm{mg} / \mathrm{mL}$. The result obtained by this method confirms those of tests DPPH and ABTS.

In toxicological studies, changes in the body weight and relative organs weights are important criteria for evaluation of organ toxicity and were used as a valuable index of insecticide-related organ damage [8]. Liver is the first organ to face any foreign molecule that is carried through portal circulation and it is subjected to most damage. It has been previously reported that during liver damage

Table 4 Effect of C. grevei MeOH extract on the activity of ALT, AST, ALP and LDH in serum and LDH in liver homogenate of mice exposed to cypermethrin

\begin{tabular}{llllll}
\hline Treatments & ALT & AST & ALP & LDH & \\
& $(\mathrm{U} / \mathrm{L})$ & $(\mathrm{U} / \mathrm{L})$ & $(\mathrm{U} / \mathrm{L})$ & Serum(U/L) & Liver(U/g tissue $)$ \\
\hline Control & $44.36 \pm 0.92^{\mathrm{a}}$ & $53.33 \pm 0.32^{\mathrm{a}}$ & $89.88 \pm 1.77^{\mathrm{a}}$ & $176.83 \pm 6.96^{\mathrm{a}}$ & $158.30 \pm 11.83^{\mathrm{b}}$ \\
Ext 150 & $45.23 \pm 0.92^{\mathrm{a}}$ & $52.82 \pm 0.24^{\mathrm{a}}$ & $90.97 \pm 1.29^{\mathrm{a}}$ & $172.87 \pm 8.38^{\mathrm{a}}$ & $160.55 \pm 10.32^{\mathrm{b}}$ \\
Ext 300 & $43.84 \pm 1.02^{\mathrm{a}}$ & $53.45 \pm 0.57^{\mathrm{a}}$ & $88.99 \pm 1.80^{\mathrm{a}}$ & $178.32 \pm 10.05^{\mathrm{a}}$ & $161.90 \pm 8.98^{\mathrm{b}}$ \\
Cyp & $60.62 \pm 1.43^{\mathrm{c}}$ & $69.39 \pm 2.33^{\mathrm{c}}$ & $131.45 \pm 3.32^{\mathrm{d}}$ & $243.21 \pm 8.23^{\mathrm{c}}$ & $114.23 \pm 4.86^{\mathrm{a}}$ \\
Cyp+ Ext 150 & $55.88 \pm 1.26^{\mathrm{b}}$ & $63.88 \pm 1.32^{\mathrm{b}}$ & $113.84 \pm 3.05^{\mathrm{c}}$ & $222.61 \pm 8.95^{\mathrm{bc}}$ & $115.04 \pm 4.91^{\mathrm{a}}$ \\
Cyp+ Ext 300 & $53.16 \pm 1.18^{\mathrm{b}}$ & $60.70 \pm 2.23^{\mathrm{b}}$ & $103.10 \pm 2.25^{\mathrm{b}}$ & $203.32 \pm 7.88^{\mathrm{b}}$ & $133.12 \pm 2.92^{\mathrm{a}}$ \\
\hline
\end{tabular}

Each value is a mean of 6 animals \pm S.E.; ${ }^{a}$ b, c, d values are not shared superscripts letters (a, b, c, d) differ significantly at $P \leq 0.05$; Con: control; Cyp: cypermethrin; Ext 150 \& Ext 300; 150 and 300 mg/ kg b.wt of C. grevei MeOH extract. ALT: alanine aminotransferases; AST: aspartate aminotransferases; ALP: alkaline phosphatase; $\mathrm{LDH}$ : lactate dehydrogenase 


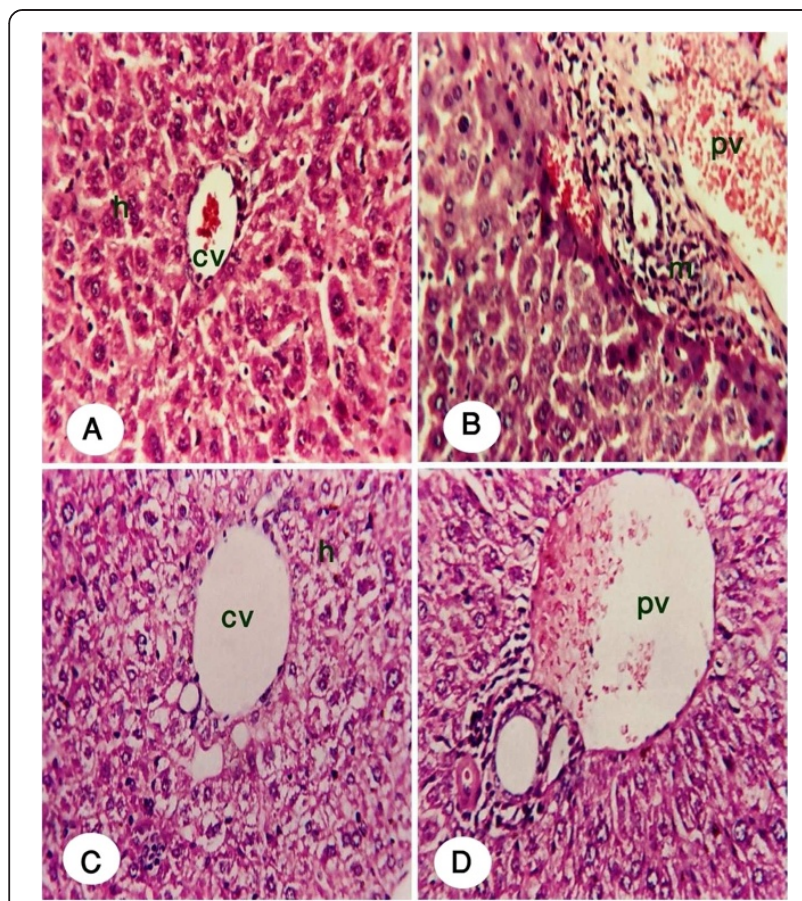

Fig. 5 Paraffin sections of liver stained by haematoxylin and eosin (H\&E) for histopathological changes. Control group and extract groups [A] showing the normal histological structure of the central vein (CV) and surrounding hepatocytes $(H)(x 40)$. Cypermethrin group showing $[B]$ degeneration in hepatocytes and dilation of portal vein with inflammatory cells infiltration ( $\mathrm{m}$ ) in the portal area (x80). Cypermethrin plus extract at $150 \mathrm{mg} / \mathrm{kg}$. b.wt. [C] showing dilatation of central vein (CV) ballooning degeneration (h) in surrounding hepatocytes (x80). Cypermethrin plus extract at $300 \mathrm{mg} / \mathrm{kg}$. b.wt. [D] showing dilatation of portal vein $(x 80)$

there was an observed decrease in antioxidant defenses in the liver [26]. In the present study, the body weights of mice treated with Cyp was markedly less while relative liver weight was increased compared to the control group. Administration of C. grevei extract at $300 \mathrm{mg} / \mathrm{kg}$ b.wt. to Cyp-intoxicated mice restored body weight to normal range and modulated significantly relative live weight to the normal control value. The decrease in body weight of Cyp treated mice was considered the result of direct toxicity and/or indirect toxicity related to the liver damage [27-29]. It may be attributed to the effect of insecticides on gastrointestinal tract resulting in decreased appetite and absorption of nutrients from gut [30]. Other investigations have reported the reduction in body weight and change in relative organs weights in Cyp-treated rats [31, 32] and in rabbits [33]

Cyp treatment induced a severe hepatic damage in serum enzyme activities of ALT, AST, ALP and LDH of male mice. The increase in serum AST, ALT and ALP enzymes may be due to liver dysfunction and disturbance in the biosynthesis of these enzymes with alteration in the permeability of the liver membrane takes place [34]. The increase in serum LDH activity may be due to the hepatocellular necrosis leading to leakage of the enzyme into the blood stream [35]. However, co-administration of C. grevei extract to Cyp-treated mice resulted in a partial recovery in the above-mentioned parameters (AST, ALT, ALP and $\mathrm{LDH})$. The high dose of C. grevei extract $(300 \mathrm{mg} / \mathrm{kg}$ ) was more effective than low dose $(150 \mathrm{mg} / \mathrm{kg})$ to attenuate the perturbations in the tested enzymes.

SOD and CAT are known to play an important role in scavenging ROS. SOD catalyzes the destruction of the superoxide radicals to $\mathrm{H}_{2} \mathrm{O}_{2}$, while CAT reduces the $\mathrm{H}_{2} \mathrm{O}_{2}$ into water and oxygen to prevent oxidative stress and in maintaining cell homeostasis. In addition, GST play essential role in the detoxification process. In the liver homogenates of Cyp-treated mice, the activities of SOD, CAT, GST and the level of GSH decreased significantly, while the level of LPO increased significantly. The change in SOD and CAT might be in response to increased oxidative stress. Considering that GST are detoxifying enzymes that catalyze the conjugation of a variety of electrophilic substrates to the thiol group of GSH, producing less toxic forms [36], the significant decrease of GST activity may indicate insufficient detoxification of Cyp in intoxicated mice.

Malondialdehyde (MDA) is a major oxidation product of peroxidized polyunsaturated fatty acids and increased MDA content is an important indicator of lipid peroxidation (LPO) [37]. In the present study, MDA level increased in mice exposed to Cyp. However, when a condition of oxidative stress strongly establishes, the defense capacities

Table 5 The severity of the reaction in liver tissue of different groups according to the histopathological alterations.

\begin{tabular}{llllll}
\hline Histopathological alterations & \multicolumn{2}{l}{ Treatment } & & & \\
& Con & Ext 150 & Ext 300 & Cyp & Cyp+ Ext 150 \\
\hline Inflammatory cell infiltration in portal area & - & - & - & +++ & - \\
Inflammatory cell infiltration in hepatic parenchyma & - & - & - & +++ & - \\
Degeneration in hepatocytes & - & - & - & ++++ & ++ \\
Congestion in portal vein & - & - & - & ++++ & - \\
Congestion in central vein & - & - & - & +++ & + \\
\hline
\end{tabular}

Con: control; Cyp: cypermethrin; Ext 150 \& Ext 300; 150 and 300 mg/ kg b.wt of C. grevei MeOH extract. ++++ Very sever; +++ Sever; ++ moderate; + mild; - nil 
against ROS becomes insufficient, in turn ROS also affect the antioxidant defense mechanisms, reduces the intracellular concentration of GSH, alters the activity of antioxidant enzymes e.g., SOD \& CAT and increase MDA. These indirectly suggest an increased production of oxygen free radicals in mice. Highly reactive oxygen metabolites, especially hydroxyl radicals, act on unsaturated fatty acids of phospholipid components of membranes to produce malondialdehyde, an LPO product [38]. However, coadministration of C. grevei extract to Cyp-treated mice resulted in a partial recovery in the above-mentioned parameters in a dose dependent manner.

The histopathological changes in liver showed that exposure of mice to Cyp resulted in degenerative changes in the liver, including degeneration, necrosis, and inflammatory cells in the portal area. The biomarkers of liver dysfunction corroborated with the histopathological lesions observed in the current study. These observations indicated marked changes in the overall histoarchitecture of liver in response to Cyp, which could be due to its toxic effects primarily by the generation of reactive oxygen species causing damage to the various membrane components of the cell. Co-administration of C. grevei extract showed marked improvement in its histological structure in comparison to Cyp-treated group alone and represented by nil to moderate degree in inflammatory cell infiltration in portal area, degeneration in hepatocytes and congestion in the portal vein and central vein.

The present study has demonstrated that C. grevei exert have a hepatoprotective effect against Cyp-induced oxidative damage and hepatotoxicity in mice. Normalized antioxidant enzymes and reduction in MDA level are likely to be the major mechanisms by which C. grevei prevented development of the liver damage. Supporting this hypothesis, we observed significant increases in SOD, CAT, and GST enzyme activity and decreases in the levels of MDA in liver tissue concomitant with insignificant changes in liver serum dysfunction biomarkers (AST, ALT, ALP and LDH) of Cyp-treated mice by the administration of $C$ grevei especially at high dose (300 $\mathrm{mg} /$ $\mathrm{kg} /$ day). This might be due to the antioxidant activity and hydroxyl radical scavenging effect of C. grevei, which sported by DPPH, ABTS scavenging activity and reducing power measurements. However, the antioxidant activity of an antioxidant compound have been attributed to various mechanisms, among which are prevention of chain initiation, binding of transition metal ion catalysts, decomposition of peroxides, prevention of continued hydrogen abstraction, reductive capacity and radical scavenging [38].

\section{Conclusion}

In view of the data of the present study, it can deduce that Cyp caused oxidative damage and liver dysfunction in male mice. C. grevei extract has protective effects on Cyp-induced lipid peroxidation, oxidative stress and liver damage. C. grevei was found to be an effective antioxidant in many in vitro assays such as DPPH, ABTS and reducing power. These results indicated that administration of C. grevei is useful, easy, and economical to protect humans against pesticides toxicity. The results presented here can be considered as the first information on the hepatoprotective and antioxidant properties of C. grevei extracts.

\section{Conflict of interests}

The authors declare that there is no conflict of interests regarding the publication of this paper.

\section{Authors' contributions}

AHM and TMH carried out the some in vitro study (reducing power, DPPH and $A B T S$ ) and in vivo study on mice (biochemical and histopathological studies). AHM and JB drafted the manuscript. MB, EGR, HF and JB carried out the plant extracts and phytochemicals determinations. AHM and JB carried out the final approval of the version to be published. All author's read and approves the final manuscript.

\section{Acknowledgments}

The authors thank the Academy of Scientific Research \& Technology (ASRT) and National Research Centre, Egypt and IMRCP UMR 5623, Faculty of Pharmacy, University Paul Sabatier (France), for supporting this study within the IMHOTEP program (Project no. 109/EGY/FR 8-02). In addition, this work was supported by the France Government through a fellowship granted by French Embassy in Egypt (Institut Francais d'Egypte). The authors are grateful to Professor Dr. Adel Mohamed Bakeer Kholoussy, Professor of Pathology, Faculty of Veterinary Medicine, Cairo University, for reading the histopathological sections.

\section{Author details}

${ }^{1}$ Environmental Toxicology Research Unit (ETRU), Pesticide Chemistry Department, National Research Centre (NRC), 33 El Bohouth Street (former El Tahrir St.), P.O. 12622, Dokki, Giza, Egypt. Faculté de pharmacie de Toulouse, Laboratoire des Interactions Moléculaires et Réactivité Chimique et Photochimique UMR CNRS 5623, Université de Toulouse, Université Paul-Sabatier, 118 route de Narbonne, F-31062 Toulouse, France. 'ªboratoire de Phytochimie et Standardisation, IMRA, BP, 3833 Antananarivo 101, Antananarivo, Madagascar. ${ }^{4}$ Nat'Ex Biotech. Bat 7, 55 avenue Louis Breguet, 31400 Toulouse, France.

Received: 25 February 2015 Accepted: 23 June 2015

Published online: 25 July 2015

\section{References}

1. Elliot M, Janes NF. Synthetic pyrethroids a new class of insecticides. Chem Soc Rev. 1978;7:473-05.

2. Cox C. Insecticide factsheet, Cypermethrin. Journal of Pesticide Reform. 1996;16:15-20.

3. Crawford MJ, Croucher A, Huston DH. Metabolism of cis and trans-cypermethrin in rats. Balance and tissue retention study. Journal of Agriculture and Food Chemistry. 1981;29:130-5.

4. Marei AEM, Ruzo LO, Casida JE. Analysis and persistance of permethrin, cypermethrin, deltamethrin and fenvalerate in the fat and brain of treated rats. Journal of Agriculture and Food Chemistry. 1982;30:558-62.

5. Desi I, Dobronyi I, Varga L. Immuno-, neuro-, and general toxicologic animal studies on a synthetic pyrethroid: cypermethrin. Ecotoxicol Environ Saf. 1986;12:220-32.

6. Baselt R. Disposition of toxic drugs and chemicals in Man, 8th edition. Foster City, CA: Biomedical Publications; 2008. p. 389-91.

7. Mansour SA, Mossa AH. Lipid peroxidation and oxidative stress in rat erythrocytes induced by chlorpyrifos and the protective effect of zinc. Pestic Biochem Physiol. 2009;93:34-9. 
8. Mossa AT, Refaie AA, Ramadan A, Bouajila J. Amelioration of prallethrin-induced oxidative stress and hepatotoxicity in rat by the administration of Origanum majorana essential oil. Biomed Research International. 2013;2013:1-11.

9. Mossa AH, Swelam ES, Mohafrash SMM. Sub-chronic exposure to fipronil induced oxidative stress, biochemical and histotopathological changes in the liver and kidney of male albino rats. Toxicology Reports. 2015; http:// dx.doi.org/10.1016/j.toxrep.2015.02.009

10. Gutteridge JM, Halliwell B. Antioxidants: molecules, medicines, and myths. Biochem Biophys Res Commun. 2010;393:561-4.

11. Mimić-Oka J, Simić T, Djukanović L, Reljić Z, Davicević Z. Alteration in plasma antioxidant capacity in various degrees of chronic renal failure. Clin Nephrol. 1999;51:233-41.

12. Nice D. Antioxidant based nutraceuticals. In: Yalpani M, editor. New technologies for healthy foods and nutraceuticals. Shrewsbury: Science Publishers; 1997. p. 105-23.

13. Mulholland DA, Kotsos M, Mahomed HA, Randrianarivelojosia M. The chemistry of the Ptaeroxylaceae. Nigerian Journal of Natural Products and Medicine. 1999;3:13-6.

14. Afoulous S, Ferhout H, Raoelison GE, Valentin A, Moukarzel B, Couderc F, et al. Chemical composition and anticancer, antiinflammatory, antioxidant and antimalarial activities of leaves essential oil of Cedrelopsis grevei. Food Chem Toxicol. 2013;56:352-62.

15. Rakotoarison O, Rabenau I, Lobstein A, Um BH, Schott C, Anton R, et al. Vasorelaxing properties and Bio-guided fractionation of Cedrelopsis grevei. Planta Med. 2003;69(2):179-81.

16. Mulholland DA, Kotsos M, Mahomed HA, Koorbanally NA, Randrianarivelojosia M, van Ufford LQ, et al. Coumarins from Cedrelopsis grevei (Ptaeroxylaceae). Phytochemistry. 2002;61(8):919-22.

17. Atmaca M, Bilgin HM, Obay BD, Diken H, Kelle M, Kale E. The hepatoprotective effect of coumarin and coumarin derivates on carbon tetrachloride-induced hepatic injury by antioxidative activities in rats. J Physiol Biochem. 2011;67(4):569-76

18. Mossa AH, Heikal TM, Mohafrash SMM, Refaie AA. Antioxidant potential and hepatoprotective activity of Origanum majorana leaves extract against oxidative damage and hepatotoxicity induced by pirimiphos-methyl in male mice. J Appl Sci. 2015;15(1):69-79.

19. Conwell DG, Jones KH, Jiang Z, Lantry LE, Keely PSW, Kohar I, et al. Cytotoxicity of tocopherols and their quinines in drug-sensitive and multidrug-resistant leukemia cells. Lipids. 1998;33:295-301.

20. Cook NC, Samman S. Flavonoids chemistry, metabolism, cardioprotective effects, and dietary sources. J Nutr Biochem. 1996;7:66-76.

21. Bruck R, Hershkoviz R, Lider O, Aeed H, Zaidel L, Matas Z, et al. Inhibition of experimentally-induced liver cirrhosis in rats by a non peptidic mimetic of the extracellular matrix associated Arg-Gly-Asp epitope. J Hepatol. 1996;24:731-8.

22. El Kar C, Ferchichi A, Attia F, Bouajila J. Pomegranate (Punica granatum) juices: chemical composition, micronutrient cations, and antioxidant capacity. J Food Sci. 2011;76:C795-800.

23. Oyaizu M. Studies on product of browning reaction prepared from glucose amine. Jpn J Nutr. 1986:44:07-315.

24. Tomlin CDS. The e-Pesticide Manual, $13^{\text {th }}$ ed, CDROM version 3.1. Farnham, UK: The British Crop Protection Councill; 2004.

25. Michael JD. The toxicologist's pocket handbook. 2nd ed. New York: Informa Healthcare USA, Inc; 2008. p. 44

26. Paris RR, Debray M. Sur les polyphénols (acides-phénols, Flavonoïdes) des feuilles de deux Méliacées malgaches : Cedrelopsis grevei Baillon et Neobeguea Leroy. Plantes Méd Phyto. 1972;6:311-9.

27. Seven A, Güzel S, Seymen O, Civelek S, Bolayirh M, Uncu M, et al. Effects of vitamin E supplementation on oxidative stress in streptozotocin induced diabetic rats: investigation of liver and plasma. Yonsei Med J. 2004:45:703-10.

28. Abbassy MA, Mossa AH. Haemato-biochemical effects of formulated and technical cypermethrin and deltamethrin insecticides in male rats. J Pharmacol Toxicol. 2012;7:312-21.

29. Sankar P, Telang AG, Manimaran A. Protective effect of curcumin on cypermethrin-induced oxidative stress in Wistar rats. Experimental Toxicology Pathology. 2012;64:487-93.

30. Venkateshwarlu P, Sharma BJR, Kalakumar B, Reddy KS, Ravikumar P. Comparative evaluation of toxicity of carbaryl, cypermethrin and malathion of testis in mice. Indian Journal of Toxicology. 1997;4:33-7.

31. Hussain S, Khan MZ, Khan A, Javed I, Asi MR. Toxico-pathological effects in rats induced by concurrent exposure to aflatoxin and cypermethrin. Toxicon. 2009;53:33-41.
32. Sangha GK, Kaur K, Khera KS, Singh B. Toxicological effects of cypermethrin on female albino rats. Toxicol Int. 2011;18:5-8.

33. Lakkawar AW, Chattopadhyay SK, Somuanshi R. Experimental cypermethrin toxicity in rabbits- a clinical and patho-anatomical study. Folia Veterinaria. 2004;48:3-8.

34. De Bruin A. Biochemical toxicology of environmental agents. Amsterdam, North Holland: Elsevier/North Holland Biochemical Press; 1979. p. 457-784.

35. Wang X, Zhai W. Cellular and biochemical in bronchoalveolar lavage fluids of rats exposed to fenvalerate. Zhongguo Yaolixue Yu Dulixue Zoghi. 1988;2:271-6.

36. Hayes D, Pulford D. The glutathione S-transferase supergene family: regulation of GST and the contribution of the isoenzymes to cancer chemoprotection and drug resistance. Crit Rev Biochem Mol Biol. 1995;30:445-600.

37. Kelly SA, Harvilla KM, Brady TC, Abrano KH, Leveir ED. Oxidative stress in toxicology: established mammalian and emerging piscine model systems. Environmental Health Perspective. 1998;106:375-84.

38. Mossa AH, Nawwar GA. Free radical scavenging and antiacetylcholinesterase activities of Origanum majorana L. essential oil. Human \& Experimental Toxicology. 2011;30:1501-13.

\section{Submit your next manuscript to BioMed Central and take full advantage of:}

- Convenient online submission

- Thorough peer review

- No space constraints or color figure charges

- Immediate publication on acceptance

- Inclusion in PubMed, CAS, Scopus and Google Scholar

- Research which is freely available for redistribution 